\title{
Hepatitis B virus DNA stability in plasma samples under short-term storage at $42^{\circ} \mathrm{C}$
}

\author{
R.W. de Almeida, M.P. Espírito-Santo, P.S.F. Sousa, A.J. de Almeida, E. Lampe and \\ L.L. Lewis-Ximenez \\ Laboratório de Hepatites Virais, Instituto Oswaldo Cruz, Fundação Oswaldo Cruz, Rio de Janeiro, RJ, Brasil
}

\begin{abstract}
We evaluated the stability of hepatitis $B$ virus (HBV) DNA in plasma samples stored at $42^{\circ} \mathrm{C}$ for external quality assessment (EQA) panels of viral load. To assess the stability of plasma samples containing different concentrations of HBV DNA, serial dilutions of HBV-infected samples with a viral load of $6.40 \log _{(10)} \mathrm{IU} / \mathrm{mL}$ were made to yield viral loads of 5 , 4, and 3 log $(10) \mathrm{IU} /$ $\mathrm{mL}$. These were incubated at $42^{\circ} \mathrm{C}$ for up to 7 days and then frozen at $-70^{\circ} \mathrm{C}$. Viral load testing for HBV DNA was performed for all samples using COBAS ${ }^{\mathbb{R}}$ AmpliPrep/COBAS ${ }^{\mathbb{R}}$ TaqMan ${ }^{\circledR}$ HBV Test (v.2.0, Roche, Switzerland). Results were compared with fresh frozen plasma samples as a benchmark to establish acceptable measurements on the days following sample collection. Although the results of this study demonstrated a decrease in HBV DNA viral load ranging from 0.005 to $0.30 \log _{(10)}$ $\mathrm{IU} / \mathrm{mL}$ after storage at $42^{\circ} \mathrm{C}$ for up to 7 days, these values did not exceed $0.5 \log _{(10)}$, which is the estimated intra-assay variation for molecular tests. Thus, the insignificant decrease in viral load suggests that shipment of HBV in plasma samples at temperatures of up to $42^{\circ} \mathrm{C}$ is permissible if they are frozen within 7 days.
\end{abstract}

Key words: HBV; Stability studies; Real-time PCR

\section{Introduction}

While serology facilitates the accurate follow-up of hepatitis $B$ virus (HBV) infection, direct detection and quantification of HBV in plasma or serum samples are routinely used to evaluate viremia in HBV-infected individuals to identify chronic infection and monitor the efficacy of antiviral therapy $(1,2)$. In recent years, real-time polymerase chain reaction (PCR)-based assays have been developed for accurate quantification of HBV DNA (3-6). These assays were designed to measure the DNA product in the early exponential amplification phase, when the reaction is most efficient, rather than at the end. The method is further enhanced by fluorescent chemistry that allows real-time monitoring of accumulating PCR products (amplicons).

Assessing the relative value of methods for detecting and quantifying HBV DNA in clinical samples is part of an important national policy articulated and pursued by the Brazilian Ministry of Health (7). Although viral DNA is more resistant to degradation than RNA under nonrefrigerated transport conditions due to its relative stability over RNA (8$13)$, it is possible that deterioration affects virus detection. Thus, this study aimed to evaluate the stability of viral DNA in HBV-positive clinical samples when transported under temperature conditions of $42^{\circ} \mathrm{C}$ for up to 7 days to reduce shipping costs.

\section{Material and Methods}

Samples were tested at the Public Central Laboratory Noel Nutels (LACEN, RJ, Brazil).

\section{Quantitative PCR assay}

Blood bank-obtained fresh frozen plasma (FFP) samples known to be negative for HIV, HCV, and HBV by serology and NAT screening were previously prepared by centrifugation at $1600 \mathrm{~g}$ and filtered through 0.45 - and $0.22-\mu \mathrm{m}$ diameter pore filters (Millipore, USA) before they were diluted. A plasma sample with an HBV DNA load of 6.40 $\log _{(10)} \mathrm{IU} / \mathrm{mL}$ was serially diluted with FFP, generating three dilutions: $1 / 10,1 / 100$, and $1 / 1000$, resulting in final concentrations of 5,4 , and $3 \log _{(10)} \mathrm{IU} / \mathrm{mL}$, respectively. To evaluate HBV stability, triplicates of these diluted HBV plasma samples were analyzed after incubation at $42^{\circ} \mathrm{C}$ for $1,2,3,4,5$, and 7 days. As control samples (baseline), triplicates of identical aliquots $\left(5,4\right.$, and $\left.3 \log _{(10)} \mathrm{IU} / \mathrm{mL}\right)$ were stored at $-70^{\circ} \mathrm{C}$ with no previous incubation at $42^{\circ} \mathrm{C}$. Triplicates of all samples of each dilution were stored at $-70^{\circ} \mathrm{C}$ every day: before (baseline, day 0 ) and after incubation at $42^{\circ} \mathrm{C}$ for up to 7 days, for a total of 63 samples for inclusion in the analysis. Following storage, samples were thawed and analyzed using the Cobas AmpliPrep/ Cobas TaqMan (CAP-CTM) assay (Roche Diagnostics,

Correspondence: R.W. de Almeida: <ricardo.almeida@ioc.fiocruz.br>.

Received May 4, 2014. Accepted November 11, 2014. First published online March 13, 2015. 
Switzerland), which has a dynamic range of linear quantification of 20 to $1.7 \times 10^{8} \mathrm{IU} / \mathrm{mL}$ (3).

\section{Statistical analysis}

HBV plasma samples incubated at $42^{\circ} \mathrm{C}$ for up to 7 days were compared with a baseline plasma sample using quantitative PCR (qPCR) data. Student's $t$-tests (two-tailed) were used to determine the significance between the mean difference of the $\log _{(10)}$-transformed HBV DNA loads. The $95 \%$ confidence intervals $(\mathrm{Cl})$ were calculated with the geometric mean (GM) and standard deviation (SD) for the log difference. A difference in DNA lower than $0.5 \log _{(10)}$ was not taken into consideration due to the estimate intra-assay SD of molecular tests $\left(0.5 \log _{(10)}\right.$ unit) (14). Data handling, analyses, and graphical representations were performed using Microsoft Excel and SigmaPlot 11.0 (USA). A P value less than 0.05 was considered to be statistically significant.

\section{Results}

A total of $63 \mathrm{HBV}$ samples containing 5,4 , and $3 \log _{(10)}$ $\mathrm{IU} / \mathrm{mL}$ HBV DNA were simultaneously subjected to nucleic acid extraction and qPCR with the CAP-CTM assay. Figure 1 shows the mean HBV load (reported as $\log _{(10)} \mathrm{IU} / \mathrm{mL}$ ) in relation to incubation time (baseline and up to 7 days) at $42^{\circ} \mathrm{C}$. A reduction in viral load less than $0.5 \log _{(10)} \mathrm{IU} / \mathrm{mL}$ was observed in all analyzed samples.

The results of HBV DNA load of the samples $(5,4$, and $3 \log _{(10)} \mathrm{IU} / \mathrm{mL}$ ) obtained by qPCR also exhibited nonsignificant intra-assay variation with an $\mathrm{SD}$ ranging from 0.005 to 0.300 . Based on the qPCR data, a statistically significant difference in the viral load of $3 \log _{(10)} \mathrm{IU} / \mathrm{mL}$ samples incubated at $42^{\circ} \mathrm{C}$ for 1 day was observed compared to a baseline sample (day 0), indicating that the HBV load loss was slightly higher at this incubation time point (Table 1). On the subsequent days (2 to 7) of incubation, no significant decline in viral load was found in relation to the baseline value. In addition, the two-sided $95 \% \mathrm{Cl}$ of the HBV DNA load difference before (baseline) and after incubation was within $0.5 \log _{(10)} \mathrm{IU} / \mathrm{mL}$, indicating the equivalence of these values. Concerning samples with 4 and $5 \log _{(10)}$ $\mathrm{IU} / \mathrm{mL}$, no significant decline was observed in the mean values for HBV DNA load before (day 0 ) and after incubation at $42^{\circ} \mathrm{C}$ for up to 7 days (Table 1 ).

\section{Discussion}

Before analyzing the value of available methods currently used by diagnostic laboratories for HBV DNA detection and quantitation, it is necessary that sample processing, storage, and transport are optimized to ensure the accuracy and reproducibility of results for viral load determination. Among the few published studies on HBV DNA stability under specific storage temperatures, José et al. (15) reported that HBV DNA stored at $5^{\circ} \mathrm{C}$ and $25^{\circ} \mathrm{C}$ was stable for at least 28 days, regardless of the initial titer. Lee et al. (16) also demonstrated that HBV DNA in plasma does not need a stabilizing solution for up to 14 days at $37^{\circ} \mathrm{C}$ or at temperatures lower than $37^{\circ} \mathrm{C}$ because HBV DNA is more stable than HCV and HIV RNA.

It is generally accepted that a variation of less than 0.5 $\log _{(10)}$ RNA/DNA copies number/mL or $0.5 \log _{(10)}$ RNA/DNA $\mathrm{IU} / \mathrm{mL}$ is acceptable in molecular assays $(14,17)$. The results of analysis of triplicate samples with $3 \log _{(10)}$ of viral load on day 1 showed a statistically significant reduction in HBV DNA load compared to FFP $(P=0.005)$. This result was an isolated finding and does not indicate viral load loss because it was neither observed in the results of the same day for 4 and $5 \log _{(10)}$ titer samples nor confirmed on subsequent days. Overall, the $95 \% \mathrm{Cl}$ was less than $0.5 \log _{(10)} \mathrm{IU} / \mathrm{mL}$ in samples tested with the Cobas AmpliPrep/Cobas TaqMan. Finally, the quantitative assays yielded reproducible results. The reproducibility of triplicate samples for different viral titers was considered excellent. The percentage of positive

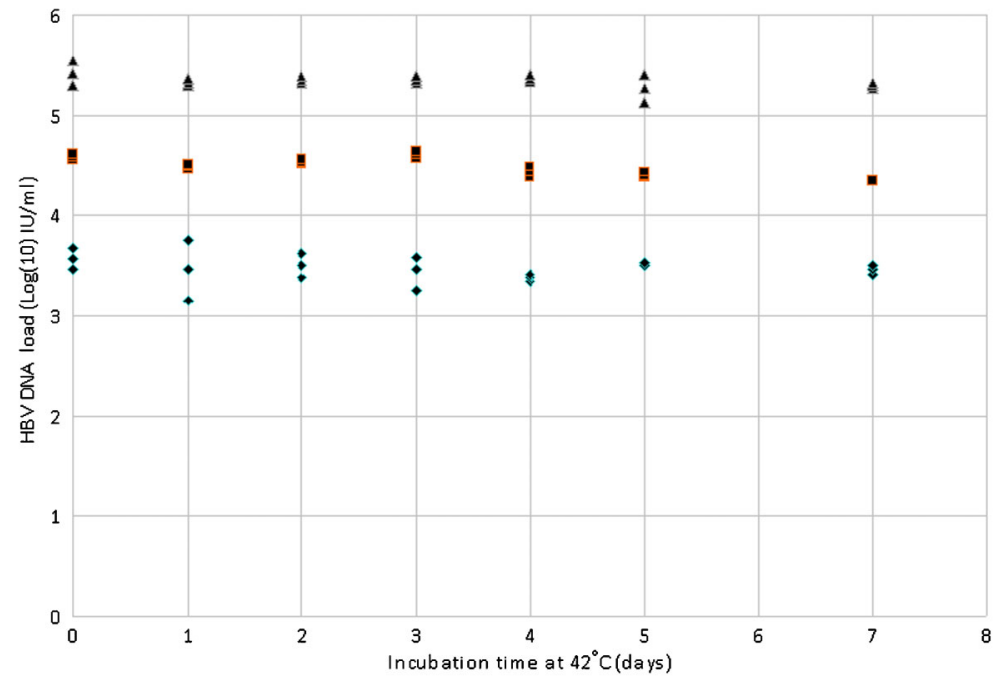

Figure 1. Mean values and standard deviations for HBV load $\left(\log _{(10)} \mathrm{IU} / \mathrm{mL}\right)$ at baseline (day 0 ) and after incubation at $42^{\circ} \mathrm{C}$ for up to 7 days using the CAP-CTM assay. Triangles: viral load of $3 \log _{(10)} \mathrm{IU} / \mathrm{mL}$. Squares: viral load of $4 \log _{(10)}$ $\mathrm{IU} / \mathrm{mL}$. Diamonds: viral load of $5 \log _{(10)} \mathrm{IU} / \mathrm{mL}$. 
Table 1. Mean values for quantity of triplicates of HBV-positive samples as determined by quantitative polymerase chain reaction before (baseline) and after incubation at $42^{\circ} \mathrm{C}$.

\begin{tabular}{lccc}
\hline Days $^{a}$ & \multicolumn{3}{c}{ Target level quantity $(\log$ molecules $\mathrm{mL}) \mathrm{GM} \pm \mathrm{SD} \log _{(10)}$} \\
\cline { 2 - 4 } & $3 \log _{(10)} \mathrm{IU} / \mathrm{mL}$ & $4 \log _{(10)} \mathrm{IU} / \mathrm{mL}$ & $5 \log _{(10)} \mathrm{IU} / \mathrm{mL}$ \\
\hline 0 (baseline) $^{\mathrm{b}}$ & $3.57 \pm 0.11$ & $4.59 \pm 0.030$ & $5.43 \pm 0.12$ \\
1 & $3.46 \pm 0.30^{*}$ & $4.49 \pm 0.017$ & $5.33 \pm 0.035$ \\
2 & $3.51 \pm 0.12$ & $4.54 \pm 0.02$ & $5.35 \pm 0.035$ \\
3 & $3.47 \pm 0.21$ & $4.61 \pm 0.026$ & $5.36 \pm 0.042$ \\
4 & $3.38 \pm 0.035$ & $4.44 \pm 0.05$ & $5.37 \pm 0.035$ \\
5 & $3.51 \pm 0.015$ & $4.41 \pm 0.03$ & $5.27 \pm 0.14$ \\
7 & $3.46 \pm 0.049$ & $4.35 \pm 0.005$ & $5.30 \pm 0.023$ \\
\hline
\end{tabular}

Data are reported as means $\pm \mathrm{SD}$. ${ }^{a}$ Days 1 up to 7 : within range of fresh frozen plasma, FFP (geometric mean, GM \pm 0.5 log); ${ }^{b}$ not incubated. ${ }^{*} \mathrm{P}<0.05$, compared to baseline (Student's $t$-test).

results within the limit of $0.5 \log _{(10)}$ of the $\mathrm{GM}$ for the samples was $100 \%$, suggesting that HBV-infected plasma samples can be shipped at temperatures up to $42^{\circ} \mathrm{C}$ within 7 days.

Dried blood spots (DBS) on filter paper have been successfully used to diagnose and monitor a number of infectious diseases (18). As a result, DBS have been used as an alternative sampling method for laboratory diagnosis, epidemiological studies, and therapeutic monitoring of viral infections. Villar et al. (19) used enzyme-linked immunosorbent assays (ELISAs) for HBsAg and anti-HBs detection in DBS samples. For HBsAg, their assay had a sensitivity of $97.62 \%$ and specificity of $96.7 \%$ and for anti-HBs, the values were $78 \%$ and $97.3 \%$, respectively. Recently, DBS cards have been used for quantification and genotyping by sequencing HBV DNA. Mohamed et al. (20) demonstrated that there were no significant differences among the $\mathrm{HBsAg}$, anti-HBs, and HBV DNA levels in DBS after 1, 3, 7, or 14 days of room temperature storage. They also determined the sensitivity and specificity of HBV DNA testing on DBS; the limit of HBV DNA detection in DBS was $914.10 \pm$ $157.77 \mathrm{IU} / \mathrm{mL}$. Some authors have provided strong evidence that the isolation and quantification of HBV from samples collected on filter paper is a viable alternative to transportation of plasma or serum samples (20). Mohamed et al. showed that the sensitivity of HBV DNA quantification in DBS samples was at least 1 log lower than that in serum samples (20). This perhaps represents the disadvantage of DBS, mainly in external quality assessment (EQA) panels.

\section{References}

1. Berger A, Braner J, Doerr HW, Weber B. Quantification of viral load: clinical relevance for human immunodeficiency virus, hepatitis $B$ virus and hepatitis $C$ virus infection. Intervirology 1998; 41: 24-34, doi: 10.1159/000024912.

2. Carman WF, Fagan EA, Hadziyannis $S$, Karayiannis $P$, Tassopoulos NC, Williams R, et al. Association of a precore genomic variant of hepatitis $B$ virus with fulminant hepatitis. Hepatology 1991; 14: 219-222, doi: 10.1002/hep.1840140203.
Most laboratories require evidence that all specimens to be tested are still stable before performing the assays, due to the wide ambient temperature range and long distances between cities. In Brazil, the ambient temperature can reach $42^{\circ} \mathrm{C}$ in some regions during certain seasons of the year. Given this characteristic of tropical countries, we ensured that HBV DNA of clinical plasma samples can be transported under temperatures up to $42^{\circ} \mathrm{C}$ without lowering the viral titer. Although the current wet sampling techniques for plasma or serum are far from being replaced by DBS sampling, this latter approach allows extension of sampling in persons and settings that are currently difficult to access or where suitable storage facilities are lacking.

The present results demonstrated that HBV can be tested in samples stored without refrigeration (up to $42^{\circ} \mathrm{C}$ ) for 7 days without a loss in accuracy. The use of ambienttemperature shipping drastically reduces shipping and logistics costs. Moreover, end users recognize an immediate cost saving because dry ice and the associated shipping materials and licensing are not required. This is of great importance for public health care because HBV DNA testing can be extended to resource-limited settings.

\section{Acknowledgments}

This research was supported by Fundação Oswaldo Cruz (FIOCRUZ) and Departamento de DST, Aids e Hepatites Virais do Ministério da Saúde, Brazil.

3. Chevaliez S, Bouvier-Alias M, Laperche S, Hezode C, Pawlotsky JM. Performance of version 2.0 of the Cobas AmpliPrep/Cobas TaqMan real-time PCR assay for hepatitis $B$ virus DNA quantification. J Clin Microbiol 2010; 48: 3641-3647, doi: 10.1128/JCM. 01306-10.

4. Noborg U, Gusdal A, Pisa EK, Hedrum A, Lindh M. Automated quantitative analysis of hepatitis $B$ virus DNA by 
using the Cobas Amplicor HBV monitor test. J Clin Microbiol 1999; 37: 2793-2797.

5. Ehrlich GD, Greenberg SJ. PCR-based diagnostics in infectious disease. Vol. 2. London: Blackwell Scientific Publications; 1994

6. Gerlich WH, Heermann KH, Thomssen R, the Eurohep Group. Quantitative assays for hepatitis B virus DNA: standardization and quality control. Viral Hep 1995; 1: 53-57.

7. Ministério da Saúde. Protocolo clínico e diretrizes terapêuticas para o tratamento da hepatite viral crônica B e coinfecções. Brasília, DF, 2011.

8. Busch MP, Wilber JC, Johnson P, Tobler L, Evans CS. Impact of specimen handling and storage on detection of hepatitis C virus RNA. Transfusion 1992; 32: 420-425, doi: 10.1046/j.1537-2995.1992.32592327714.x.

9. Gessoni G, Barin P, Valverde S, Giacomini A, Di NC, Orlandini $E$, et al. Biological qualification of blood units: considerations about the effects of sample's handling and storage on stability of nucleic acids. Transfus Apher Sci 2004; 30: 197-203, doi: 10.1016/j.transci.2003.11.010.

10. Ginocchio CC, Wang XP, Kaplan MH, Mulligan G, Witt D, Romano JW, et al. Effects of specimen collection, processing, and storage conditions on stability of human immunodeficiency virus type 1 RNA levels in plasma. $J$ Clin Microbiol 1997; 35: 2886-2893.

11. Grant PR, Kitchen A, Barbara JA, Hewitt $P$, Sims CM, Garson JA, et al. Effects of handling and storage of blood on the stability of hepatitis C virus RNA: implications for NAT testing in transfusion practice. Vox Sang 2000; 78: 137-142, doi: 10.1046/j.1423-0410.2000.7830137.x.

12. Krajden M, Minor JM, Rifkin O, Comanor L. Effect of multiple freeze-thaw cycles on hepatitis B virus DNA and hepatitis $C$ virus RNA quantification as measured with branched-DNA technology. J Clin Microbiol 1999; 37: 1683-1686.
13. Sebire K, McGavin K, Land S, Middleton T, Birch C. Stability of human immunodeficiency virus RNA in blood specimens as measured by a commercial PCR-based assay. J Clin Microbiol 1998; 36: 493-498.

14. Baleriola C, Johal H, Jacka B, Chaverot S, Bowden S, Lacey $S$, et al. Stability of hepatitis $C$ virus, HIV, and hepatitis $B$ virus nucleic acids in plasma samples after long-term storage at -20 degrees $C$ and -70 degrees C. J Clin Microbiol 2011; 49: 3163-3167, doi: 10.1128/JCM.02447-10.

15. José M, Gajardo R, Jorquera JI. Stability of HCV, HIV-1 and HBV nucleic acids in plasma samples under long-term storage. Biologicals 2005; 33: 9-16, doi: 10.1016/j.biologicals 2004.10.003.

16. Lee DH, Li L, Andrus L, Prince AM. Stabilized viral nucleic acids in plasma as an alternative shipping method for NAT. Transfusion 2002; 42: 409-413, doi: 10.1046/j.1525-1438. 2002.00068.x.

17. Pawlotsky JM. Measuring hepatitis $C$ viremia in clinical samples: can we trust the assays? Hepatology 1997; 26: 14, doi: 10.1002/hep.510260131.

18. Lira R, Maldonado-Rodriguez A, Rojas-Montes O, RuizTachiquin M, Torres-lbarra R, Cano-Dominguez C, et al. Use of dried blood samples for monitoring hepatitis $B$ virus infection. Virol J 2009; 6: 153, doi: 10.1186/1743-422X-6153.

19. Villar LM, de Oliveira JC, Cruz HM, Yoshida CF, Lampe E, Lewis-Ximenez LL. Assessment of dried blood spot samples as a simple method for detection of hepatitis B virus markers. J Med Virol 2011; 83: 1522-1529, doi: 10.1002/jmv.22138.

20. Mohamed S, Raimondo A, Penaranda G, Camus C, Ouzan $D$, Ravet $S$, et al. Dried blood spot sampling for hepatitis $B$ virus serology and molecular testing. PLoS One 2013; 8: e61077, doi: 10.1371/journal.pone.0061077. 